\title{
Legalisasi Deklarasi HAM ASEAN
}

\section{Imelda Masni Juniaty Sianipar}

Universitas Kristen Indonesia

Cawang, Jakarta 13630

Email: imelda.sianipar@uki.ac.id

\begin{abstract}
On November 18, 2012, ASEAN countries signed ASEAN Human Rights Declaration. Since structured as a draft, this declaration has drawn controversy. The supporters argued that the declaration is a starting point for ASEAN countries to respect human rights. The Opponents considered that the declaration actually provide opportunities for ASEAN countries to commit human rights violations. Although both arguments are right, there is one thing that need to be underlined that the ten ASEAN countries have already signed the ASEAN Human Rights Declaration. This paper will examine the legalization of the ASEAN Human Rights Declaration. By examining its three dimensions -obligation, precision and delegation- ASEAN Human Rights Declaration is categorized as a soft legalization. The obligation of ASEAN Human Rights Declaration is low because it has no binding force. All ASEAN countries do not have obligation to implement the articles of the declaration. The precision of the declaration is also low because the words used in the declaration are ambiguous. It provides opportunities for the members of ASEAN countries to interpret them in different ways. Finally, the delegation of the declaration is also low because there is no third party that has authority to monitor the states' compliance to the declaration and resolve conflicts that arise in case of human rights violations.

Keywords: legalization, ASEAN human rights declaration, states compliance, human rights, ASEAN
\end{abstract}

\begin{abstract}
Abstrak
Pada 18 November 2012, Negara-negara ASEAN menandatangani ASEAN Human Rights Declaration. Karena terstruktur sebagai draft, deklarasi ini mengundang kontroversi. Para pendukung berpendapat bahwa deklarasi tersebukan merupakan poin awal Negara-negara ASEAN untuk menghargai HAM. Para lawan menganggap bahwa deklarasi ini justru memberikan peluang pada Negara-negara ASEAN untuk melakukan pelanggaran HAM. Meskipun kedua argumen benar adanya, terdapat satu hal yang patut digarisbawahi, yakni bahwa sepuluh Negara anggota ASEAN telah menandatangani ASEAN Human Rights Declaration. Artikel ini akan menguji legalisasi ASEAN Human Rights Declaration. Dengan menguji tiga dimensi, obligasi, presisi, dan delegasi-ASEAN Human Rights Declaration dikategorikan sebagai soft legalization. Kewajiban atas ASEAN Human Rights Declaration dikategorikan lemah karena tidak adanya kekuatan yang mengikat. Seluruh Negara ASEAN tidak memiliki kewajiban untuk melaksanakan isi dari deklarasi. Presisi dari deklarasi juga lemah karena bahasa yang digunakan dalam deklarasi terkesan ambigu. Hal ini memberikan peluang pada masing-masing anggota ASEAN menerjemahkannya dengan cara yang berbeda. Akhirnya, delegasi dari deklarasi juga lemah karena tidak ada pihak ketiga yang memiliki wewenang untuk mengawasi kepatuhan Negara-negara terhadap deklarasi dan menyelesaikan masalah yang timbul dalam kasus pelanggaran HAM.

Kata Kunci: legalisasi, ASEAN human rights declaration.
\end{abstract}

\section{PENDAHULUAN}

Konferensi Tingkat Tinggi ASEAN ke-21 yang berlangsung di Phonm Penh, Kamboja, pada 18 - 20 November 2012 telah membuat sebuah capaian penting dalam konteks hak asasi manusia. Perdana Menteri Malaysia, Datuk Seri Najib Razak, Presiden Filipina Benigno S. Aquino, Perdana Menteri Singapura Lee Hsien Loong, Perdana Menteri Thailand Yingluck Shinawatra, Perdana Menteri Vietnam Nguyen Tan Dung, Perdana Menteri Kamboja Hun
Sen, Sultan Brunai Darussalam Hassanal Bolkiah, Presiden Indonesia Susilo Bambang Yudhoyono, Perdana Menteri Laos Thongsing Thammavong dan Presiden Myanmar U Thein Sein yang merupakan kepala negara dari negara-negara ASEAN menandatangi Deklarasi HAM ASEAN (ASEAN Human Rights Declaration). Konferensi tersebut dihadiri pula oleh para pemimpin penting dunia antara lain Presiden Amerika Serikat Barack Obama, Perdana Menteri China Wen Jiabao, Presiden Korea Selatan Lee Myung- 
bak, Perdana Menteri Jepang Yoshihiko Noda, Perdana Menteri India Manmohan Singh, Perdana Menteri Australia Julia Gillard, dan Perdana Menteri Selandia Baru John Key dan Menteri Luar Negeri Rusia Sergey Lavrov.

Negara-negara anggota ASEAN, yaitu Brunei Darussalam, Kamboja, Indonesia, Malaysia, Myanmar, Laos, Thailand, Vietnam, Filipina, dan Singapura, memiliki hukum, sistem pemerintahan, dan kondisi HAM yang berbeda-beda. Karenanya, kehadiran deklarasi tersebut diharapkan dapat menyamakan persepsi dan memperbaiki perlindungan hak asasi manusia di kawasan berpenduduk 600 juta tersebut. Selain itu juga deklarasi juga diharapkan dapat menjadi standard HAM di negara-negara anggota ASEAN.

Deklarasi HAM ASEAN merupakan salah satu mandat dari ASEAN Intergovernmental Commission on Human Rights (AICHR) atau Komisi Antar-Pemerintah ASEAN untuk Hak Asasi Manusia. AICHR berdiri pada 23 Oktober 2009 berdasarkan Piagam ASEAN pasal 14, yang memandatkan pembentukan komisi HAM di ASEAN. Komisi ini selanjutnya memiliki tugas penting yaitu menyusun draf tentang deklarasi HAM ASEAN. ${ }^{1}$

Kawasan Asia Pasifik termasuk Asia Tenggara merupakan satu-satunya kawasan di dunia yang belum memiliki instrumen hak asasi manusia regional. Kawasan Eropa memiliki Konvensi Eropa tentang Perlindungan HAM dan Kebebasan Dasar/Convention for the Protection of Human Rights and Fundamental Freedoms sejak 1950. Kawasan Amerika memiliki Konvensi Amerika tentang HAM/American Convention on Human Rights sejak 1969. Kawasan Afrika memiliki Piagam Afrika mengenai HAM dan Hak-hak Rakyat/ African Charter on Human and Peoples' Rights sejak 1979. ${ }^{2}$ Karenanya, deklarasi HAM ASEAN ini merupakan sebuah capaian yang penting bagi kawasan Asia khususnya Asia Tenggara. Deklarasi HAM ASEAN memuat bagaimana seharusnya penegakan HAM diterapkan sekaligus dipromosikan di kawasan ASEAN. Deklarasi ini juga memuat pandangan dan sikap negara-negara ASEAN tentang HAM. ${ }^{3}$
Meskipun deklarasi HAM ASEAN merupakan sebuah capaian penting namun deklarasi tersebut tidak luput dari kritik. Beberapa kelompok menganggap deklarasi HAM sebagai kemunduran penegakan HAM di ASEAN. Badan PBB dan masyarakat sipil menilai deklarasi HAM ASEAN telah merendahkan martabat manusia dan membatasi upaya perlindungan hak asasi manusia berdasarkan standard universal. ${ }^{4}$ Pelaksanaan HAM ASEAN yang harus mempertimbangkan konteks nasional dan regional dapat memberikan peluang bagi rezim pemerintah otoriter ASEAN untuk menjustifikasi tindakantindakan mereka yang tidak sesuai dengan standar HAM. Selain itu, proses perancangan draft deklarasi HAM ASEAN yang kurang transparan telah memicu protes dari masyarakat sipil. ${ }^{5}$

Tulisan ini akan menyoroti Deklarasi HAM ASEAN yang telah menuai kontroversi tersebut. Penulis akan meneliti legalisasi deklarasi HAM ASEAN tersebut berdasarkan dimensi obligasi, presisi dan delegasinya. Dengan demikian akan didapati suatu pemahaman tentang karakter yang dimiliki oleh deklarasi tersebut dan bagaimana implikasinya terhadap kepatuhan negara-negara ASEAN pada deklarasi tersebut.

\section{PEMBAHASAN}

DEFINISI LEGALISASI

Kenneth W. Abbott, dkk mendefinisikan legalisasi sebagai a particular set of characteristics that institutions may (or may not) possess. ${ }^{6}$ Karakteristik tersebut meliputi tiga dimensi yaitu obligasi, presisi dan delegasi. Obligasi berarti negara atau pihak yang berjanji diikat oleh aturan atau komitmen. Dengan demikian, negara atau pihak yang berjanji memiliki kewajiban untuk tunduk pada aturan atau komitmen yang telah disepakati. Presisi berarti bahwa aturan-aturan tersebut jelas, menegaskan perilaku yang diwajibkan, diwewenangkan dan di larang oleh aturan-aturan tersebut. Sedangkan delegasi berarti adanya pihak ketiga yang diberikan wewenang untuk mengimplementasikan, menginterpretasikan dan menerapkan aturan; menyelesaikan konflik atau perselisihan dan membuat aturan-aturan baru. ${ }^{7}$ 
Dimensi obligasi, presisi dan delegasi dari suatu aturan memiliki tingkatan yang berbeda-beda. Jika dimensi obligasi, presisi dan delegasinya tinggi maka legalisasi aturan tersebut tinggi (hard legalization). Jika dimensi obligasi, presisi dan delegasinya rendah maka legalisasi aturan tersebut rendah (soft legalization). Jika salah satu dari dimensi obligasi, presisi dan delegasinya tinggi atau rendah maka legalisasi dari aturan tersebut sedang (medium legalization). ${ }^{8}$ Gambar 1 dibawah ini memperlihatkan masing-masing elemen dari legalisasi. Masing-masing elemen ditampilkan dari bentuk yang paling lemah yang terletak di sebelah kiri hingga ke bentuk yang paling kuat yang terletak di sebelah kanan gambar.

\begin{tabular}{|c|c|c|c|}
\hline Obligation & $\begin{array}{l}\text { Expressly } \\
\text { non legal norm }\end{array}$ & $\longleftrightarrow$ & $\begin{array}{l}\text { Binding rule } \\
\text { (jus cogens) }\end{array}$ \\
\hline Precision & $\begin{array}{l}\text { Vague } \\
\text { principles }\end{array}$ & & $\begin{array}{l}\text { Precise, highly } \\
\text { elaborated rule }\end{array}$ \\
\hline Delegation & Diplomacy & $\longleftrightarrow$ & $\begin{array}{l}\text { International court, } \\
\text { organization, } \\
\text { domestic application }\end{array}$ \\
\hline
\end{tabular}

\section{Gambar 1. Dimensi Legalisasi ${ }^{9}$}

Menurut Abbot dan Snidal, para pihak termasuk negara memiliki berbagai pertimbangan yang mengarahkan mereka untuk menyepakati aturan yang bersifat hard law dan soft law. Istilah hard law digunakan untuk menyebut aturan yang memiliki kekuatan mengikat yang jelas dan memberikan wewenang kepada pihak ketiga untuk menginterpretasikan dan mengimplementasikan aturan tersebut. ${ }^{10}$ Abbot dan Snidal mengamati bahwa baik hard law dan soft law, keduanya memiliki keuntungan dan kerugian. Beberapa keuntungan yang dapat diperoleh dengan menyepakati aturan yang bersifat hard law adalah mengurangi biaya transaksi, memperkuat kredibilitas komitmen, memperluas strategi politik dan memecahkan masalah yang tidak dapat diselesaikan dalam perjanjian yang tidak lengkap. Sedangkan kerugian dari hard law yaitu terbatasnya keleluasaan aktor untuk bertindak dan bahkan membatasi kedaulatan. Akibat dari terlalu ketat dan kakunya aturan yang bersifat hard law maka para pihak / negara lebih menyukai perjanjian yang bersifat soft law. Adapun keuntungan dari soft law adalah mengurangi biaya transaksi seperti biaya negosiasi-pertemuan, mempelajari isu-tawar menawar-dan lain-lain, tidak mempengaruhi kedaulatan, memberikan sejumlah alternatif menarik untuk mengantisipasi ketidakpastian. Sementara itu kelemahan dari soft lawadalah sulitnya memegang komitmen negara/para aktor untuk taat pada peraturan.

Pada umumnya para pihak/negara lebih suka mengikatkan diri pada perjanjian yang bersifat soft law dibandingkan hard law. Hal ini dikarenakan soft law dianggap lebih banyak memberi ruang gerak bagi negara dibandingkan hard law. Terlebih bila menyangkut dengan kedaulatan negara.

\section{MENGAPA DEKLARASI ? \\ Deklarasi merupakan sebuah dokumen yang} menyatakan persetujuan resmi tentang standar-standar tertentu namun tidak memiliki kekuatan mengikat. ${ }^{11}$ Deklarasi HAM ASEAN merupakan sebuah dokumen yang menyatakan persetujuan resmi dari 10 negara anggota ASEAN tentang standar hak asasi manusia yang berlaku di lingkungan ASEAN. Deklarasi HAM ASEAN memuat prinsip-prinsip umum yang terdiri dari 9 pasal; hak-hak sipil dan politik yang terdiri dari 16 pasal; hak-hak ekonomi, sosial dan budaya yang terdiri dari 9 pasal; hak pembangunan yang terdiri dari 3 pasal, hak untuk hidup damai yang terdiri dari 1 pasal; dan kerjasama dalam memajukan dan melindungi hak asasi manusia yang terdiri dari 2 pasal.

Seluruh isi pasal yang tercantum dalam deklarasi HAM ASEAN tersebut baru mengikat secara moral, belum secara yuridis. Karenanya ada kemungkinan negara-negara ASEAN tidak mematuhi pasal-pasal yang tercantum dalam deklarasi tersebut. Sebuah pertanyaan penting pun muncul. Apa yang memotivasi negara-negara ASEAN memilih deklarasi sebagai sebuah aturan dasar dalam rangka memajukan dan melindungi hak asasi manusia.

Menurut Miles Kahler, sudah menjadi ciri khas bagi 
negara-negara di kawasan Asia baik Asia Tenggara, Asia Timur, Asia Selatan bahkan Asia Pasifik bahwa mereka lebih menyukai aturan- aturan yang bersifat longgar. ${ }^{12}$ Hasil pengamatan Kahler terhadap tiga institusi yang ada di kawasan Asia yaitu ASEAN, ARF dan APEC membuktikan hal tersebut. Paling tidak ada tiga alasan yang menyebabkan negara-negara di kawasan Asia lebih menyukai aturan-aturan yang longgar. Pertama, telah tersedianya aturan alternatif di luar deklarasi ASEAN sehingga tuntutan untuk memiliki aturan yang lebih mengikat jadi rendah. Misalnya Malaysia, Indonesia, Singapura sudah meratifikasi konvensi Hak Asasi Manusia Internasional 1966 karenanya mereka tidak terlalu membutuhkan aturan yang lebih mengikat berkaitan dengan pelaksanaan hak asasi manusia.

Kedua, negara-negara ASEAN yakin bahwa mereka mampu menyelesaikan masalah mereka dengan caracara ASEAN. Prinsip ini dikenal dengan ASEAN Way yang mengedepankan keharmonisan, konsensus dan pertemuan-pertemuan informal dalam menyelesaikan persoalan yang muncul. Bagi negara-negara ASEAN, prinsip penyelesaian masalah dengan gaya ASEAN harus tetap dipertahankan. Hal tersebutlah yang membedakan ASEAN dengan institusi lain yang merupakan ciptaan barat. ASEAN sendiri sudah merupakan implementasi dari pemikiran barat karenanya perlu menambahkan sesuatu yang merupakan ciri khas pemikiran timur yang dikenal dengan ASEAN Way.

Ketiga, politik domestik negara-negara ASEAN yang menyebabkan sulitnya membuat aturan yang lebih mengikat di kawasan. Kecuali Thailand, negara-negara ASEAN memiliki pengalaman historis yang sama yaitu pernah mengalami masa penjajahan. Trauma akan penjajahan ini membuat para pemimpin ASEAN tidak menginginkan adanya aturan yang terlalu membatasi perilaku negara. Kedaulatan adalah di atas segalagalanya. Selain memiliki pengalaman historis yang sama, keanekaragaman sistem politik di ASEAN mempersulit negara-negara di ASEAN untuk berada dalam satu aturan yang mengikat terlalu kuat. ${ }^{13}$ Filipina merupakan negara yang menerapkan sistem politik yang demokratis.Malaysia dan Singapura memiliki sistem politik yang demokratis namun pada prakteknya didominasi oleh satu partai dominan. Barisan Nasional telah mendominasi Malaysia dan Partai Aksi Rakyattelah menjadikan Singapura seperti negara dengan sistem satu partai. Sistem politik Indonesia telah mengalami beberapa fase. Setelah mengalami demokrasi parlementer pada awal 1950, sistem politik Indonesia berubah menjadi otoriter dibawah demokrasi terpimpin pada masa kepemimpinan Soekarno. Selanjutnya pada 19651998, Indonesia dikuasai oleh rezim Soeharto yang memiliki gaya kepemimpinan otoritarianisme yang anti komunis dan pro-militer. Setelah jatuhnya Soeharto pada tahun 1998, Indonesia mulai mengarah pada demokrasi. Thailand didominasi oleh rezim militer dan mulai mengarah pada demokrasi sejak awal 1990. Kamboja dibawah kepemimpinan Hun Sen mengadopsi sistem demokrasi namun pada prakteknya bersikap otoriter. Vietnam dan Laos menerapkan sistem komunis yang otoriter. Myanmar merupakan negara yang didominasi oleh rezim militer dan Brunai Darussalam merupakan negara yang menerapkan sistem kesultanan. ${ }^{14}$

\section{TINGKAT OBLIGASI, PRESISI DAN DELEGASI DEKLARASI HAM ASEAN}

Seperti yang telah disebutkan di atas, dimensi obligasi berarti negara atau pihak yang berjanji diikat oleh aturan atau komitmen yang telah disepakati. Dengan demikian, negara memiliki kewajiban untuk tunduk pada aturan atau komitmen tersebut. Dalam kaitannya dengan deklarasi HAM ASEAN, seluruh negara-negara anggota ASEAN tidak memiliki kewajiban untuk menaati pasal-pasal yang tercantum dalam deklarasi tersebut. Hal ini dikarenakan deklarasi tidak memiliki kekuatan mengikat. Deklarasi hanya menuntut moral negara-negara ASEAN untuk menghormati dan melindungi hak asasi setiap individu yang ada di negara-negara ASEAN sesuai dengan pasalpasal dalam deklarasi HAM ASEAN. Jika negara-negara ASEAN melanggar atau bersikap tidak patuh pada isi dalam deklarasi tersebut, mereka tidak akan dikenakan sanksi. Sanksi yang diberikan hanya bersifat sanksi 
moral/normatif. Dengan demikian maka dapat dikatakan bahwa tingkat obligasi deklarasi HAM ASEAN adalah rendah.

Dilihat dari tingkat presisinya, deklarasi HAM ASEAN juga rendah. Pernyataan atau kata-kata yang digunakan pada pasal-pasal dalam deklarasi tersebut bersifat ambigu. Karenanya masing-masing negara ASEAN dapat memberikan interpretasi yang berbedabeda mengenai isi pasal tersebut. Beberapa pasal yang dapat menimbulkan penafsiran berbeda-beda antara lain ditemukan pada pasal 7 dan 8 dari deklarasi HAM ASEAN.

Pasal 7 menyatakan bahwa;

"All human rights are universal, indivisible, interdependent and interrelated. All human rights and fundamental freedoms in this Declaration must be treated in a fair and equal manner, on the same footing and with the same emphasis. At the same time, the realisation of human rights must be considered in the regional and national context bearing in mind different political, economic, legal, social, cultural, historical and religious backgrounds."15

Pasal ini menyatakan bahwa realisasi hak asasi manusia di ASEAN harus mempertimbangkan konteks regional dan nasional. Akan tetapi konteks regional dan nasional yang dimaksud tidak diuraikan secara jelas sehingga masing-masing negara akan memiliki interpretasi yang berbeda-beda mengenai konteks regional dan nasional tersebut.

Pasal 8 menyatakan bahwa

"The human rights and fundamental freedoms of every person shall be exercised with due regard to the human rights and fundamental freedoms of others. The exercise of human rights and fundamental freedoms shall be subject only to such limitations as are determined by law solely for the purpose of securing due recognition for the human rights and fundamental freedoms of others, and to meet the just requirements of national security, public order, public health, public safety, public morality, as well as the general welfare of the peoples in a democratic society." ${ }^{16}$

Pasal ini menekankan bahwa semua hak yang disediakan dalam Deklarasi harus mempertimbangkan ketahanan nasional, aturan publik, kesehatan publik, keamanan publik dan moral publik. Akan tetapi pasal tersebut tidak memberi rincian yang jelas mengenai konsep-konsep yang dimaksud. Hal ini dapat memberikan penafsiran yang berbeda-beda pada masing-masing negara ASEAN. Konsep kesehatan publik dalam standard Singapura tentu berbeda dengan Indonesia. Demikian pula halnya dengan moral publik Singapura yang juga berbeda standard moral publiknya Indonesia.

Dengan mengacu pada tiga pasal tersebut maka dapat dikatakan bahwa deklarasi HAM ASEAN memiliki dimensi presisi yang rendah. Deklarasi HAM ASEAN memiliki celah dan peluang bagi masingmasing negara menerjemahkan isi pasal tersebut dengan cara yang berbeda-beda. Hal ini berbahaya karena negara-negara ASEAN dapat saja menerjemahkan isi pasal tersebut sesuai dengan kepentingannya masing-masing.

Delegasi deklarasi ASEAN juga rendah karena tidak ada pihak ketiga yang memiliki wewenang untuk memonitor kepatuhan negara-negara ASEAN terhadap deklarasi dan menyelesaikan masalah jika terjadi pelanggaran HAM di salah satu negara ASEAN. Pelanggaran HAM yang dilakukan oleh Myanmar yang bersikap diskriminatif terhadap kelompok muslim Rohingya tidak dapat diselesaikan oleh ASEAN karena tidak ada badan yang memiliki wewenang untuk memberikan sanksi terhadap Myanmar akibat pelanggaran HAM yang telah dilakukannya. AICHR yang diharapkan menjadi pihak yang berwenang dalam penegakan HAM ASEAN tidak bisa berbuat banyak karena dalam perkembangannya badan ini hanya menjadi wadah persaudaraan dan tempat berdiskusi tentang kondisi HAM di masing-masing negara ASEAN.

Berdasarkan penjelasan di atas mengenai dimensi obligasi, presisi dan delegasi dari deklarasi HAM ASEAN maka nampak bahwa ketiga dimensi tersebut rendah. Karenanya deklarasi HAM ASEAN merupakan aturan yang memiliki legalisasi rendah (soft law).

KRITIK TERHADAP DEKLARASI HAM ASEAN 
Deklarasi HAM ASEAN telah menuai kritik tajam dari masyarakat baik di tingkat nasional, regional, dan internasional. Paling tidak, ada enamhal yang menjadi kritik dari masyarakat. Pertama, pertimbangan konteks nasional dan regional dalam pemberlakuan HAM.

Deklarasi HAM ASEAN mengakui hak asasi manusia bersifat universal dan fundamental, namun dalam realisasinya, negara-negara anggota ASEAN harus mempertimbangkan konteks regional dan nasional, termasuk perbedaan politik, ekonomi, hukum, sosial, budaya, sejarah, dan latar belakang agama. Hal ini berarti negara-negara ASEAN telah mengakui HAM seperti standar internasional, tetapi pelaksanaannya harus sesuai dengan konteks regional dan nasional. Menurut, salah satu aktivis HAM Indonesia, Usman Hamid, pengakuan HAM berdasarkan pertimbangan konteks nasional dan regional dapat menimbulkan masalah. Misalnya saja pada persoalan perlindungan minoritas agama. Pemerintah Indonesia dapat menganggap pemeluk Islam yang berkeyakinan Syiah tidak sesuai dengan agama yang diakui atau latar belakang budaya yang diakui secara nasional. Padahal sebenarnya hak-hak yang melekat pada pemeluk Islam yang berkeyakinan Syiah diakui dan dijamin oleh Deklarasi HAM Universal. Pertimbangan konteks nasional yang dilakukan oleh pemerintah Indonesia dapat mengancam kebebasan beragama pemeluk agama Islam yang berkeyakinan Syiah tersebut. ${ }^{17}$

Kedua, penyeimbangan hak dan kewajiban individual, komunitas dan masyarakat lainnya. Menurut Yuyun Wahyuningrum, Senior Advisor ASEAN and Human Rights di Human Rights Working Group (HRWG), Deklarasi HAM ASEAN tidak seharusnya mendefinisikan hubungan timbal balik antara hak dan kewajiban individu, kelompok dan masyarakat dalam kerangka HAM karena kerangka HAM tidak mengenal konsep penyeimbangan antara hak dan kewajiban. HAM bersifat melekat, tidak dapat dibagi, saling bergantung, dan berhubungan antara satu dengan lainnya. ${ }^{18}$

Ketiga, pertimbangan ketahanan nasional, aturan publik (public order), kesehatan publik (public health), keamanan publik (public safety), dan moral publik (public morality). Deklarasi HAM ASEAN tidak seharusnya mempertimbangkan ketahanan nasional, aturan publik, kesehatan publik, keamanan publik dan moral publik dalam pelaksanaan HAM karena hal ini secara tidak langsung justru membatasi setiap individu untuk menerima hak-nya secara utuh. Pemerintah dapat membatasi hak warganegaranya dengan pertimbangan-pertimbangan tersebut. Misalnya tentang public morality. Isu ini merupakan isu yang dikritisi gerakan perempuan di ASEAN. Pemerintah seringkali bertindak diskriminasi terhadap kaum perempuan dengan mengatasnamakan agama dan moralitas. Sementara ukuran moralitas bisa didefinisikan dan ditentukan secara berbeda-beda oleh setiap individu atau segolongan orang yang mendominasi, seperti kelompok-kelompok fundamental. Sering kali pemenuhan hak perempuan di Indonesia terhambat public morality yang memang masih subjektif dan tidak jelas standarnya. ${ }^{19}$

Keempat, deklarasi HAM ASEAN juga dikritisi karena tidak menyebutkan secara tegas mengenai hakhak kelompok minoritas yang lain seperti masyarakat adat dan kelompok lesbi, gay, biseksual dan transgender (LGBT). Hal ini memperlihatkan bahwa negara-negara ASEAN cenderung mengabaikan hak asasi kelompok minoritas tersebut. Hal ini dikarenakan kelompokkelompok minoritas seperti masyarakat adat dan LGBT termasuk dalam kelompok rentan dan marginal. ${ }^{20}$

Kelima, deklarasi HAM tidak memenuhi standar hak asasi manusia internasional. Hal ini dinyatakan oleh Komisaris Perserikatan Bangsa Bangsa untuk Hak Asasi Manusia, Navy Pillay dan Phil Robertson, wakil direktur Human Rights Watch. Deklarasi HAM ASEAN yang tidak memenuhi standar hak asasi manusia internasional dapat membuka banyak celah dan pembenaran bagi pemerintah negara ASEAN untuk mengabaikan hak rakyatnya.

Keenam, aktivis HAM juga mengkritik proses perancangan draf. Menurut para aktivis HAM, proses perancangan draf dilakukan secara tertutup atau tidak transparan dan meniadakan konsultasi dengan masyarakat sipil. Draf Deklarasi tidak pernah dibagi 
dan dipublikasikan untuk mendapatkan masukan konstruktif. Di beberapa negara bahkan tidak digelar proses konsultasi sama sekali. Proses konsultasi baru dilakukan menjelang proses akhir pengesahan Deklarasi. Karenanya, para aktivis HAM menganggap deklarasi HAM ASEAN tersebut sebagai pengkhianatan terhadap hak asasi manusia.

\section{HAL POSITIF DARI DEKLARASI HAM ASEAN}

Berdasarkan uraian di atas terlihat jelas bahwa deklarasi HAM ASEAN masih memiliki kelemahankelemahan. Mengenai hal tersebut Sekretaris Jenderal ASEAN, Surin Pitsuwan berjanji akan melakukan evaluasi terhadap deklarasi tersebut. ${ }^{21}$ Menteri Luar Negeri Kamboja Hor Namhong mengatakan bahwa kehadiran deklarasi HAM ASEAN merupakan sebuah langkah yang baik dan tidak perlu dipersoalkan terlalu jauh. Deklarasi HAM ASEAN yang telah ditandatangani saat ini masih bisa diperbaiki dan ditingkatkan di masa mendatang.

Meskipun deklarasi HAM ASEAN diakui memiliki beberapa kelemahan, dalam beberapa hal, deklarasi ini memperlihatkan kemajuan-kemajuan terutama terkait hak perempuan dan anak. Pada pembukaan deklarasi terdapat pernyataan yang menegaskan kembali Deklarasi Penghapusan Kekerasan terhadap Perempuan di ASEAN. Deklarasi ini sudah ada sejak tahun 2004. Dengan penegasan kembali tersebut membuktikan keseriusan negara-negara ASEAN untuk melindungi hak perempuan dan menghapus kekerasan terhadap perempuan. ${ }^{22}$

Selain dalam pembukaan, pembahasan tentang hak perempuan dan anak dapat ditemukan juga pada Prinsip Umum pasal 4, di mana di dalamnya disebutkan bahwa hak perempuan, anak, lanjut usia, penyandang disabilitas, serta kelompok rentan dan marginal merupakan satu bagian yang tidak terpisahkan dan integral dari HAM dan kebebasan fundamental. Pasal ini secara ekplisit menyebutkan tentang hak perempuan sebagai hak asasi manusia. ${ }^{23}$ Deklarasi HAM itu juga menyebutkan bahwa negaranegara ASEAN memberikan perlindungan khusus kepada ibu dalam masa sebelum dan setelah melahirkan. Pernyataan tersebut tercantum pada pasal 30 ayat 2 dan 3.

Selain itu, deklarasi juga mewajibkan negara-negara ASEAN untuk melaksanakan pembangunan yang berorientasi pada rakyat dan gender responsive. Negaranegara ASEAN dalam setiap pembangunannya harus peka terhadap persoalan-persoalan perempuan terkait dengan penghapusan kemiskinan. ${ }^{24} \mathrm{Hal}$ tersebut dinyatakan pada pasal 36 deklarasi HAM ASEAN.

\section{SITUASI HAM ASEAN PASCA DEKLARASI}

Meskipun negara-negara ASEAN telah membuat kesepakatan untuk menghormati dan melindungi hak asasi setiap individu di ASEAN, pada prakteknya negara-negara ASEAN masih melakukan berbagai pelanggaran terhadap hak asasi manusia.

Di Myanmar, pemerintah membuat panduan yang ketat bagi para jurnalis. Mereka tidak boleh menyebarkan berita yang berkaitan dengan korupsi, obat-obatan terlarang dan buruh anak. ${ }^{25}$ Di Malaysia, pemerintah mengamandemen Evidence Act yang membatasi kebebasan berekspresi surat kabar, stasiun radio dan stasiun televisi. Aturan tersebut menyatakan bahwa pemilik surat kabar, pemilik stasiun radio, pemilik stasiun televisi, pengurus administrasi, penyiar, editor, penjual dan pelayan jaringan bertanggung jawab terhadap isi berita yang mereka terbitkan. ${ }^{26}$ Di Thailand, pemerintah melarang masyarakatnya mengkritik keluarga kerajaan dengan menggunakan undang-undang lese majeste dan Computer Crimes Act. ${ }^{27}$ Pada September 2011, pemerintah Yingluck menangkap Surapak Phuchaisaeng (pendukung Kaos Merah) karena diduga menyebarkan berita yang menghina keluarga kerajaan melalui facebook. Surapak Phuchaisaeng kemudian dibebaskan pada 31 Oktober 2013 oleh Pengadilan Kriminal Bangkok karena terbukti tidak bersalah. Meskipun kasus penghinaan terhadap keluarga kerajaan tersebut tidak terbukti, hingga saat ini, pemerintah Thailand tetap menggunakan undang-undang lese majeste yang terdapat dalam Kitab Undang-undang Hukum Pidana pasal 112 dan Computer Crimes Act untuk membatasi kebebasan berekspresi masyarakat Thailand. 
Di Vietnam, pemerintah mengawasi dengan ketat stasiun radio, stasiun televisi dan perusahaan penerbit. Pemerintah memberikan hukuman yang tegas bagi para pemilik stasiun radio, stasiun televisi dan perusahaan penerbitan yang menyebarkan informasi tentang penentangan terhadap pemerintah, mengancam keamanan nasional, membocorkan isu-isu rahasia negara atau ide-ide yang radikal. Pemerintah juga memblokir akses terhadap website-website penting dan meminta pemilik cafe atau restaurant untuk memonitor dan menyimpan informasi yang diunduh oleh para pengunjung cafe atau restaurant selama mereka online di internet. Pemerintah juga memerintahkan Menteri Keamanan Publik untuk menutup blog-blog dan websitewebsite yang tidak mendapat persetujuan dari pemerintah dan memberikan hukuman kepada para pembuat blog dan website tersebut. ${ }^{28}$

Tindakan yang dilakukan oleh Myanmar, Malaysia, Thailand dan Vietnam di atas jelas bertentangan dengan isi dari deklarasi HAM ASEAN mengenai kebebasan berekspresi. Pasal 23 deklarasi ASEAN menyatakan bahwa setiap individu memiliki hak berpendapat dan berekspresi termasuk kebebasan mengeluarkan pendapat tanpa campur tangan pihak lain dan mencari dan menerima informasi baik secara lisan maupun tulisan melalui media yang disukai oleh individu tersebut. Berdasarkan fakta di atas terlihat jelas bahwa pemerintah Myanmar, Thailand dan Vietnam masih membatasi kebebasan berekspresi masyarakatnya dan hal ini bertentangan dengan pasal 23 deklarasi HAM ASEAN.

Selain membatasi kebebasan berekspresi, negaranegara ASEAN juga membatasi kekebasan beragama masyarakatnya. Hal ini bertentangan dengan pasal 22 deklarasi HAM ASEAN. Di Myanmar, pemerintah masih melakukan tindakan diskriminatif terhadap sekitar satu juta penduduk rohingya dengan menggunakan Discriminatory Citizenship Law 1982. Hingga saat ini, pemerintah masih menggunakan hukum tersebut untuk membatasi hak masyarakat rohingya mendapatkan pendidikan, pekerjaan dan kebebasan untuk berpindah ke wilayah lain. ${ }^{29} \mathrm{Di}$ Vietnam, pemerintah mewajibkan setiap kelompok keagamaan mendaftarkan organisasi atau institusinya kepada pemerintah. Berbagai kelompok keagamaan tersebut harus menjalankan ritual keagamaannya sesuai petunjuk pemerintah. Jika mereka melakukan kegiatan yang bertentangan dengan petunjuk pemerintah, mereka akan ditangkap dan dipenjarakan oleh pemerintah. Sejauh ini, pemerintah Vietnam telah menangkap 18 anggota dari kelompok keagaamaan Budha di provinsi Phu Yen karena aktivitas mereka dianggap ingin menjatuhkan pemerintah. Pemerintah juga menangkap dan memenjarakan Pastor Nguyen Cong dari Provinsi Gia Lai selama 11 tahun karena pemerintah menduga aktivitasnya dapat merusak persatuan dan kesatuan bangsa. Selanjutnya, pemerintah juga menangkap para aktivis Protestan etnik Hmong dari distrik Muong Nhe dan memenjarakan mereka selama dua setengah tahun karena pemerintah menganggap aktivitas mereka mengganggu keamanan nasional. Untuk membenarkan aksinya tersebut, Pemerintah Vietnam menggunakan Kitab Undang-undang Hukum Pidana pasal 87.

Beberapa negara ASEAN juga masih melakukan tindakan diskriminatif terhadap kelompok marginal tertentu. Pemerintah Malaysia menentang kehadiran kelompok lesbi, gay, biseksual dan transgender (LGBT) di negara tersebut. Perdana Menteri Malaysia, Datuk Seri Najib Razak menyatakan bahwa aktivitas LGBT tidak diijinkan di Malaysia. Najib mewajibkan masyarakat Malaysia untuk menentang dan melawan perilaku LGBT. Najib menyampaikan pernyataannya ini di hadapan 11.000 Imam dan anggota majelis masjid. ${ }^{30}$ Hal yang sama juga terjadi di Singapura. Kelompok LGBT Singapura melaporkan kepada Human Rights Watch bahwa mereka sering mendapat perlakuan yang tidak wajar. Pemerintah Singapura seringkali menyiksa dan menganiaya mereka. ${ }^{31}$ Tindakan Malaysia dan Singapura ini tentu saja bertentangan dengan deklarasi HAM ASEAN yang menganggap bahwa setiap individu memiliki hak dan derajat yang sama. Pernyataan ini terdapat pada prinsip umum deklarasi HAM ASEAN pasal 1. 


\section{KESIMPULAN DAN SARAN}

Deklarasi HAM ASEAN disepakati sebagai bentuk penghormatan negara-negara ASEAN terhadap hak asasi manusia. Dilihat dari ketiga dimensinya, deklarasi tersebut memiliki tingkat obligasi rendah, presisi rendah dan delegasi rendah. Obligasi rendah karena para pihak tidak memiliki kewajiban untuk menjalankan isi deklarasi HAM. Presisi rendah karena pernyataan-pernyataan dalam deklarasi bersifat ambigu. Masing-masing negara dapat memiliki interpretasi berbeda-beda tentang pernyataan-pernyataan dalam deklarasi. Pernyataan yang bersifat ambigu terutama dapat ditemukan pada pasal 6, 7 dan 8. Delegasi rendah karena tidak ada pihak ketiga yang memiliki wewenang untuk memonitor kepatuhan negara pada deklarasi dan memberikan sanksi kepada negara-negara ASEAN yang melakukan pelanggaran HAM. Karena ketiga dimensi menunjukkan derajat yang rendah maka deklarasi HAM ASEAN memiliki legalisasi rendah atau dikategorikan sebagai soft law.

Pasca penandatanganan deklarasi, negara-negara ASEAN masih melakukan tindakan yang melanggar hak asasi manusia. Myanmar, Malaysia, Thailand dan Vietnam masih membatasi kebebasan berekspresi masyarakatnya. Hal ini bertentangan dengan pasal 22 deklarasi HAM ASEAN. Pembatasan terhadap kebebasan beragama juga masih ditemukan di Myanmar dan Vietnam. Hal ini bertentangan dengan pasal 23 deklarasi HAM ASEAN. Sementara itu, Malaysia dan Singapura juga melakukan tindakan diskriminatif terhadap kelompok minoritas tertentu seperti kelompok LGBT. Hal ini sangat tidak sesuai dengan prinsip umum deklarasi HAM ASEAN pasal 1.

Melihat fakta-fakta tersebut maka perlu sekali untuk melakukan evaluasi terhadap deklarasi HAM ASEAN. Derajat legalisasi aturan HAM ASEAN perlu ditingkatkan. Terutama setelah ditemukannya berbagai kelemahan dalam deklarasi HAM ASEAN. Aturan HAM ASEAN perlu ditingkatkan menjadi aturan yang lebih mengikat seperti protokol atau konvensi. Hal ini bisa dilakukan dengan bantuan dari para pakar HAM seperti Komisaris Perserikatan Bangsa Bangsa untuk Hak Asasi Manusia, Navy Pillay dan Phil Robertson, wakil direktur Human Rights Watch. Mereka dapat memberi masukan yang konstruktif kepada negaranegara ASEAN untuk lebih serius menghormati hak asasi manusia. Selain itu, perlu juga rekontruksi ide dalam pemikiran para pemimpin ASEAN. Perspektif para pemimpin ASEAN terhadap negara-negara tetangga harus berubah. Perasaan curiga terhadap negara tetangga harus segera diubah dengan menganggap mereka sebagai teman dan sahabat. Hal ini penting untuk menumbuhkan rasa saling percaya antar sesama anggota ASEAN sehingga mereka bersedia dikontrol oleh institusi lain. Apabila kedua hal tersebut bisa diterapkan maka ada kemungkinan aturan HAM ASEAN dapat ditingkatkan menjadi sebuah aturan yang lebih mengikat.

\section{CATATAN AKHIR}

1 Mandat ini tercantum pada term of reference of ASEAN Intrergovernmental Commission on Human Rights pasal 4 ayat 2.

2 http://www.satjiptorahardjoinstitute.org/artikel/mengapresiasideklarasi-ham-asean/ diakses pada 23 Oktober 2013 pukul 21.01 WIB.

3 Ibid.

4 http://www.ohchr.org/EN/Countries/AsiaRegion/Pages/ AsiaPacificProgramme11-12.aspx diakses pada 23 Oktober 2013 pukul 21.05 WIB.

5 http://indonesia.ucanews.com/2012/11/20/aktivis-deklarasi-hamasean-sebagai-kemunduran-penegakan-ham-di-indonesia/ diakses 18 Oktober 2013 pukul 19.20 WIB.

6 Kenneth W. Abbott, Robert O. Keohane, Andrew Moravcsik, AnneMarie Slaughter, Duncan Snidal, The Concept of Legalizationdalam Judith Goldstein, Miles Kahler, Robert O. Keohane, Anne-Marie Slaughter, (International Organization, Volume 54, Number 3, Summer 2000), 401

7 Ibid.

8 Ibid.,402.

9 Ibid.,404

10 Kenneth W. Abbott dan Duncan Snidal, Hard and Soft Law in International Governance, dalam Judith Goldstein et al., Op.Cit., 421.

11 http://www1.umn.edu/humanrts/edumat/hreduseries/hereandnow/ Part-5/6_glossary.htm diakses pada 20 Oktober 2013 pukul 23.00 WIB.

12 Miles Kahler, Legalization as Strategy: The Asia-Pacific Case dalam Judith Goldstein et al., Op.Cit.,549-550.

13 lbid, 559-561

14 Derek McDougal, Asia Pacific in World Politics (Boulder: Lynne Rienner Publishers,2007) 19

15 Ibid.

16 lbid

17 http://indonesia.ucanews.com/2012/11/20/aktivis-deklarasi-ham- 
asean-sebagai-kemunduran-penegakan-ham-di-indonesia/

18 http://www.hukumonline.com/berita/baca/t5063269e00520/hrwgkritik-substansi-deklarasi-ham-asean diakses pada 15 Oktober 2013 pukul 22.10 WIB.

19 http://network.vhrmedia.com/new/ berita_detail.php?id $=478 \mathrm{r}=0 \& \mathrm{~kat}=0 \& \mathrm{PageNo}=0$ diakses pada 20 Oktober 2013 pukul 20.15 WIB.

$20 \mathrm{http}: / /$ www.vhrmedia.com/new/ berita_detail.php? $\mathrm{id}=478 \mathrm{r}=0$ \&kat $=0 \&$ PageNo $=0$ diakses pada 19 Oktober 2013 pukul 22.10 WIB.

21 http://indonesia.ucanews.com/2012/11/20/aktivis-deklarasi-hamasean-sebagai-kemunduran-penegakan-ham-di-indonesia/

22 http://www.vhrmedia.com/new/ berita_detail.php?id $=478 \mathrm{r}=0 \& \mathrm{~kat}=0 \&$ PageNo $=0$

23 Ibid.

24 Ibid.

25 Human Rights Watch, World Report 2013: Events 2012 (United States of America: 2005)286

26 Ibid.,332

27 Ibid., 375

28 Ibid., 383

29 Ibid., 289

30 Ibid., 335

31 Ibid., 365

\section{BIBLIOGRAFI}

Abbot, Kenneth W. and Duncan Snidal, Hard and Soft Law in International Governance. International Organization. Volume 54, Number 3, Summer 2000.

Abbott, Kenneth W, Robert O. Keohane, Andrew Moravcsik, AnneMarie Slaughter and Duncan Snidal. The Concept of Legalization.International Organization, Volume 54, Number 3 , Summer 2000.

ASEAN Human Rights Declaration

Goldstein, Judith., Miles Kahler, Robert O. Keohane and Anne-Marie Slaughter. International Organization. Volume 54, Number 3 , Summer 2000.

Human Rights Watch. World Report 2013: Events 2012. United States of America: 2005.

Kahler, Miles. Legalization as Strategy: The Asia-Pacific Case.International Organization, Volume 54, Number 3, Summer 2000.

McDougal, Derek. Asia Pacific in World Politics. Boulder: Lynne Rienner Publishers,2007.

Term of Reference of ASEAN Intrergovernmental Commission on Human Rights

http://www.satjiptorahardjoinstitute.org/artikel/mengapresiasi-deklarasiham-asean/

http://www.ohchr.org/EN/Countries/AsiaRegion/Pages/ AsiaPacificProgramme11-12.aspx

http://indonesia.ucanews.com/2012/11/20/aktivis-deklarasi-ham-aseansebagai-kemunduran-penegakan-ham-di-indonesia/

http://www1 umn.edu/humanrts/edumat/hreduseries/hereandnow/ Part-5/6_glossary.htm

http://www.vhrmedia.com/new/ berita_detail. php? $\mathrm{id}=478 \mathrm{r}=0$ \&kat $=0 \&$ Page $\mathrm{No}=0$ 